\section{B.M.J. $1861-1908$}

Mr. O. M. Symons, sub-librarian of the Penzance Library, Cornwall, informs us that that library has on its shelves the British Medical Journal from volume i, 1861, to 1908 . $\mathrm{He}$ asks whether there is any institution or society to whom the volumes would be of interest.

\section{Incem 3 Tax}

Car Allowance

"C. R. W. L." owned two cars the written-down values of which at April, 1935, were $£ 72$ and $£ 198=£ 270$. He sold them for $£ 244$, and bought a new car on May 15th, 1935, for $£ 324$. He ceased general practice on July 15th. What can he claim?

${ }_{*}^{*}$ Assuming that he is entitled to an adjustment of the 1935-6 assessment, in so far as it applies to the period April 5th to July 15th, he can claim as a professional expense of that period $£ 270-£ 244=£ 26$ as an "obsolescence" allowance. So far as "depreciation" is concerned he will have received an allowance for 1935-6, and that will remain, but subject to restriction to the period to July 15th, 1935. The right to the "adjustment" referred to above will arise: (a) if he was in sole practice, and $(b)$ if he was in partnership, and the past and present partners combine with him in electing to have the practice regarded as having ceased and recommenced as at July 15 th, 1935 .

\section{Car Expenses}

“G. M. L." refers to a suggestion made seven or eight years ago that $£ 250$ was a reasonable-amount to charge for running a car. The inspector of taxes now states that $£ 150$ is regarded as adequate.

${ }_{*}^{*}$ Taking into account the greatly reduced cost of a car suitable for normal work, and consequently the reduced annual depreciation, it must probably be agreed that a smaller charge for car expenses is due than was the case eight years ago. At the same time circumstances differ so much between practices that any attempt to suggest a proper annual charge might be misleading. We suggest that "G. M. L." can probably obtain a better estimate of the average running costs of his car from his garage manager than we could give him. Depreciation should be excluded and claimed separately, and, of course, a deduction will have to be made for private use.

\section{Foreign Resident--Dividends}

"L.M. \& S." lives permanently in India, and derives income from Great Britain and Northern Ireland in the form of dividends from which United Kingdom income tax is deducted. What claim can he make for repayment?

** Residence outside the United Kingdom does not confer exemption in respect of income arising within the country. But under Section 24 of the Finance Act of 1920 a British subject residing abroad is entitled to the usual allowances in the ratio that his total income bears to the British income. Thus if "L.M. \& S.'s" British income is one-fifth of his total income, he can claim repayment up to tax on one-fifth of the statutory allowances. He should apply for the appropriate form of claim to Chief Inspector of Taxes (Foreign Claims), Cornwall House, Stamford Street, London, S.E.1.

\section{Board and Lodging of Maid}

" J. P." was allowed a deduction of $£ 52$ under the above head in a former practice. The inspector of taxes now dealing with his assessment refused to allow more than £30, but on representations being made to headquarters a compromise of $£ 40$ has been agreed. " J. P." would like to know definitely what amount he is entitled to deduct.

** There is no "definite" amount, because the correct sum is determined by the actual expenditure, and that differs widely according to locality, the standard of food and comfort supplied, and, presumably, economy of household management. $£ 52$ is a not uncommon amount allowed, but the only way of proving any particular claim is to ascertain the total expenditure and show what is the appropriate allocation to the domestic staff.

\section{LETTERS, NOTES, ETC.}

\section{Treatment of Pneumonia}

Dr. H. M. Berncastle (South Croydon) writes: I am diffident about making the following statement because it appears so obvious and simple. Pneumococci being aerobic and facultative anaerobes, the giving of oxygen as treatment is tantamount to feeding them on what they need and helping them to increase and multiply. I am constrained to make this comment on oxygen treatment by a case I had fairly recently. A strong, healthy woman about 30 was reported to me by my senior assistant colleague as having pneumonia. I examined, and agreed with the diagnosis-a small area of consolidation at the left angle of the scapula with classical symptoms. My colleague, who was right up to date with modern treatment, suggested early oxygen ; to this I agreed, and it was duly given. The patient was dead within three days, and, post mortem, I have never seen a more massive double pneumonia. I cannot remember ever seeing a case of pneumonia which came to the oxygen stage ever recovering, but of course it eases the symptoms of distress and it is a great comfort to relatives to see it being given. I have it in my mind that early treatment with $\mathrm{CO}_{2}$ gas would be a more logical line to take. I have recently heard of an experiment in which a squad of men were kept in a sealed room for twelve hours without suffering any particular discomfort, although matches would not light in the room at the end of the experiment owing to the $\mathrm{CO}_{2}$ gas present. As we have no specific for pneumonia of any distinct value, I suggest that investigation on the above lines might prove of interest. Older practitioners will remember cases of wonderful crises and recoveries without any complications when the hygienic conditions for nursing were as bad as they could be and fresh air religiously excluded.

\section{Red Cross Day}

Lord Ebbisham writes: As chairman of the Appeals Committee of the British Red Cross Society I should like to be permitted to draw the attention of your readers to Red Cross Day, held on the anniversary of Florence Nightingale's birthday, Tuesday, May 12th. The work of the British Red Cross Society has expanded continuously since the great war, and its activities at home and abroad are in urgent need of support. In England the society has over 25,000 members helping the suffering, the helpless, the ignorant, and the injured. It has ambulances and first-aid stations all over the country, clinics for rheumatism and orthopaedic clinics, organization for blood transfusion, and dispensaries for hop pickers and herring fishers. At the request of the Government we have placed our organization at its disposal in connexion with the enrolment and training of personnel for anti-gas services, and in the task of instructing the general public in air raid precautions. Abroad the British Red Cross Society has two units in Abyssinia rendering aid to the Ethiopian sick and disabled. Red Cross Day is the one occasion during the year when the society can appeal to the man in the street to give generously to its work of mercy. I ask everyone to spare as much as he possibly can, and thus enable a record collection to be made on Red Cross Day-May 12th-in 1936.

\section{Corrigenda}

An error intruded into para. 237 of the Epitome in the issue of March 14th. The journal epitomized should have been denoted as Il Policlinico, Sez. Chir., January 15th, 1936, p. 1.

In Mr. R. T. Payne's article on treatment of varicose diseases of the lower limbs in our issue of May 2nd the word "removed" appeared for " reviewed" at the foot of column two of page $\mathbf{8 8 0}$. The sentence should have read: "All varicose vein cases should be reviewed, say, three months after the completion of injections."

\section{Vacancies}

Notifications of offices vacant in universities, medical colleges, and of vacant resident and other appointments at hospitals, will be found at pages $49,50,51,52,53,54,55,56,57,60$ and 61 of our advertisement columns, and advertisements as to partnerships, assistantships, and locumtenencies at pages 58 and $\mathbf{5 9}$.

A short summary of vacant posts notified in the advertisement columns appears at page $\mathbf{9 7 8}$. 